\title{
Developing Guideline on Patient and Family Education in Promoting Mental Health and Preventing Schizophrenia
}

\author{
Shaqina Said ${ }^{1, *}$, Muhammad Farhan Maruli ${ }^{2}$, Hervita Diatri ${ }^{3}$ \\ ${ }^{1,2}$ Faculty of Medicine, Universitas Indonesia, Jakarta, Indonesia \\ ${ }^{3}$ Department of Psychiatry, Faculty of Medicine, Universitas Indonesia, Jakarta, Indonesia \\ *Corresponding Author. E-mail: shaqina.said@gmail.com
}

\begin{abstract}
Schizophrenia is a significantly disabling condition which affects more than 400,000 people in Indonesia. However, only $84.9 \%$ of people with schizophrenia in Indonesia seek medical help and only $48.9 \%$ of those adhere to medication. Another problem in Indonesia is pasung (shackling), which occurs in $31.5 \%$ of patients with schizophrenia. Education of patients and families plays a role in alleviating these problems. However, the are no guidelines on patient and family schizophrenia education in Indonesia. This review aims to present recommendations for developing guideline on patient and family schizophrenia education in Indonesia. We conducted this review in MEDLINE database and search engine. The inclusion criteria were articles in English or Indonesian within the last 20 years. The used keywords were schizophrenia, education, family, screening, adherence, shackling, primary healthcare, their synonyms, as well as their equivalent in the Indonesian language. Analysis of selected papers suggests that people attributed schizophrenia symptoms to myths and there are barriers in accessing information and healthcare services. Schizophrenia education should be implemented in primary healthcare facilities. The content of education should consist of schizophrenia facts, symptoms, treatments, support, recovery and relapse prevention, and prevention of pasung. More studies on the content and method of education are warranted.
\end{abstract}

Keywords: schizophrenia, education, family, health promotion, prevention

\section{INTRODUCTION}

Schizophrenia is a group of severe mental disorders characterized by distortions of thinking and perception [1], [2]. Common symptoms of schizophrenia include delusions, hallucinations, disorganized thinking, and retreat from reality [1], [2]. According to Riset Kesehatan Dasar (Riskesdas) 2018, more than 400,000 people in Indonesia are affected by the disorder [3]. However, this number may be an underestimation as the global prevalence rate of schizophrenia reaches $0.75 \%$ [4].

Schizophrenia is significantly disabling [5]. It affects all major areas of the life of the patient [5]. Not only does schizophrenia affect the patient; the caregiver is also affected by the disorder. Caregiver of a schizophrenic patient experience high burden in the physical, emotional, and economic domains [6].

The consensus to treat schizophrenia is to combine antipsychotic medication and psychosocial interventions [7]. However, only $84.9 \%$ of people with schizophrenia in Indonesia seek medical help. Furthermore, only $48.9 \%$ of those who seek treatment adhere to medication [8]. Another problem faced by people with schizophrenia in Indonesia is pasung (shackling). As many as $31.5 \%$ of patients with schizophrenia are currently being shackled, and another $14 \%$ have experienced shackling in the past [8].

Education of patients and families plays a role in alleviating these problems [9], [10]. There are evidence that in low- and middle-income countries, community-based psychosocial interventions which include psychoeducation are feasible and have positive effects on the functional outcome of people with schizophrenia [7].

A systematic review and meta-analysis by Asher L, et al. compares previous studies on schizophrenia psychoeducational intervention on the areas of education duration and content, delivery method, type of personnel delivering the intervention, community involvements, and outcome [7]. However, the studies reviewed do not address the main problems of schizophrenia in Indonesia: identifying the disorder, treatment adherence, and preventing pasung. This review aims to present recommendations for developing guideline on patient and family schizophrenia education in Indonesia.

\section{METHOD}

We conducted a search in the MEDLINE database and using the Google search engine from 1999 through 20 September 2019. A search in the MEDLINE database was 
conducted for each of three domains: A: identifying schizophrenia, B: improving treatment adherence, and C: preventing pasung (shackling). Table 1 concludes the search strategy used in this study for the MEDLINE database.

Table 1. MEDLINE Search Strategy

\begin{tabular}{|c|c|}
\hline Domain & Keywords \\
\hline A: Identifying schizophrenia & $\begin{array}{l}\text { ("Schizophrenia" [MeSH]) AND (Education* OR psychoeducation OR stigma OR } \\
\text { perception) AND (Screening OR case?finding OR help?seeking OR symptom* OR } \\
\text { diagnos*) AND (family OR caregiver* OR community) AND ((primary } \\
\text { health?care) OR (community health cent*) OR (health?care cent*)) }\end{array}$ \\
\hline B: Treatment adherence & $\begin{array}{l}\text { ("Schizophrenia" [MeSH]) AND (Education* OR psychoeducation OR stigma or } \\
\text { perception) AND (treat* OR therap* OR manag* OR medic* OR intervention\$) } \\
\text { AND (Adherence OR compliance OR non?adherence OR non?compliance OR (side } \\
\text { effect\$) OR (adverse effect\$) OR (adverse event\$) OR (adverse reaction) OR } \\
\text { outcome OR prognosis) AND (family OR caregiver* OR community) AND } \\
\text { ((primary health?care) OR (community health cent*) OR (health?care cent*)) }\end{array}$ \\
\hline C: Preventing pasung & $\begin{array}{c}\text { ("Schizophrenia" [MeSH]) AND (Shackl* OR confin* OR restrain* OR (physical } \\
\text { restrain*) OR chain*) AND (family OR caregiver* OR community) }\end{array}$ \\
\hline
\end{tabular}

The titles and abstracts retrieved from each domain searched were screened for relevance. In all domains, studies were limited to (1) studies in human, (2) reported in English or Indonesian language, (2) in subject with schizophrenia, and (3) in urban and rural area. For domain A: identifying schizophrenia, the added eligibility criteria were (1) qualitative studies or case reports in identifying schizophrenia, or (2) experimental studies on educational intervention that covers identifying the disorder. For domain B: treatment adherence, the added eligibility criterion was (1) experimental studies on educational intervention with treatment adherence as an outcome. For domain C: preventing pasung, the added eligibility criterion was (1) qualitative studies or case reports describing physical restraints and confinements in people with schizophrenia.

The exclusion criteria for all domains of study were (1) full article not available from the publisher, (2) subjects are adolescent or children, (3) educational intervention uses electronic method, and (4) education conducted in highincome countries. The studies were then screened for duplicates.

We also conducted a literature search using the Google search engine. The used search terms are schizophrenia, education, family, screening, adherence, shackling, primary healthcare, their synonyms, as well as their equivalent in the Indonesian language. The included results were journal articles on psychoeducational intervention on schizophrenia patient and family. 


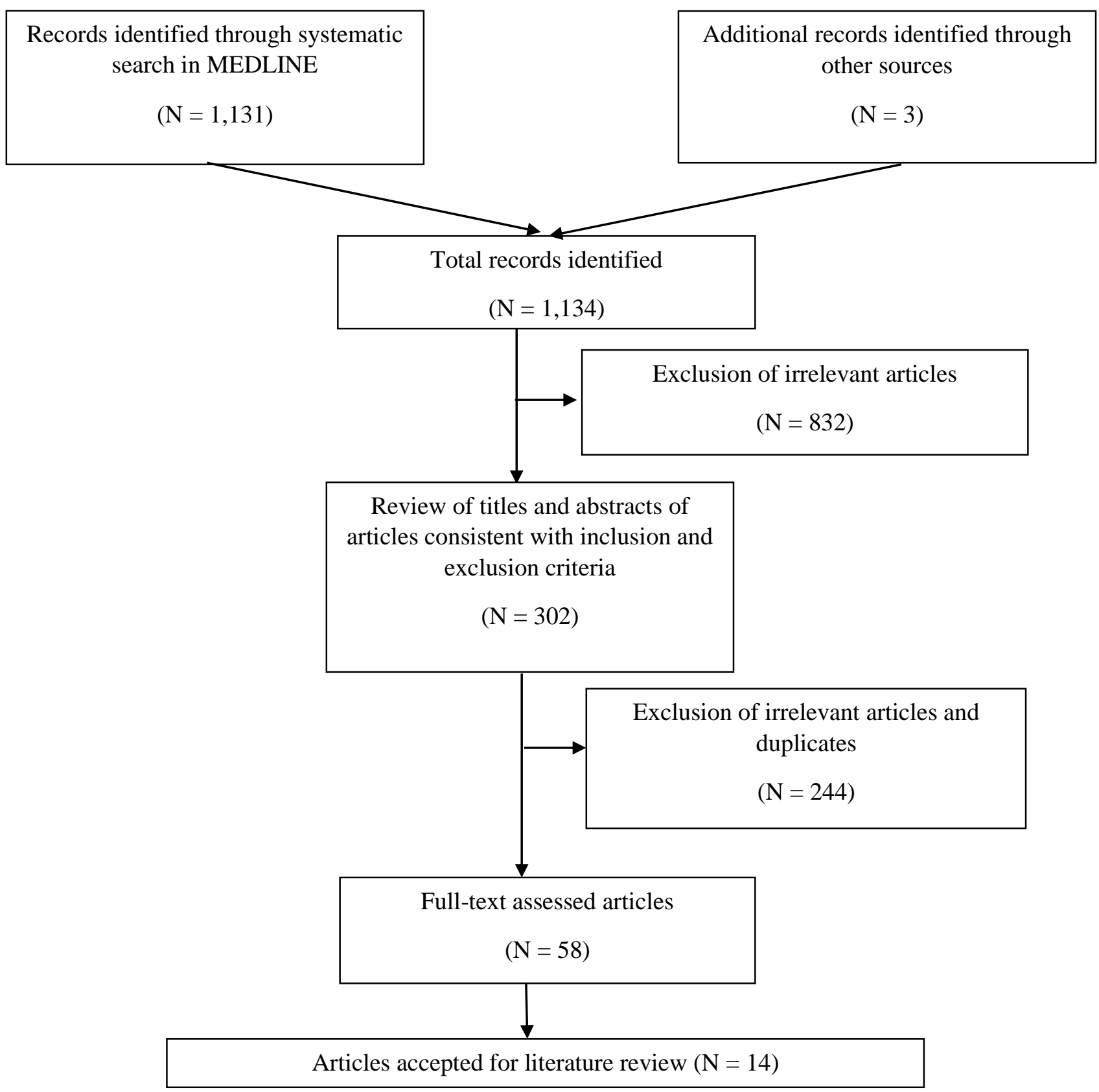

Figure 1. Selection of articles

\section{RESULTS AND DISCUSSION}

Results from the analysis of the data from the selected 14 articles signifies that the patient and family education of schizophrenia address the three domains of problems in schizophrenia: identifying the disorder, treatment adherence, and pasung.

\section{Identifying schizophrenia}

One qualitative study in Jordan found that people diagnosed with schizophrenia and their family had attributed symptoms of schizophrenia to sudden fright, possession by evil spirits, sorcery, punishment by God, head trauma, emotional trauma, bad genes and multiple personality disorder. There is also social stigma with the view that a person's weak faith or sins cause mental illness [11]. Patients and their family members may not have access to information clarifying these myths due to stigma [11].

Another study reported a lack of information about the nature and meaning of schizophrenia. This resulted in increased anxiety about schizophrenia and beliefs about having a 'split personality' as well as beliefs about posing a risk of harming others [12]. A study in India found that most caregivers were uncertain about the nature and cause of 
schizophrenia or attributed it to multiple causes simultaneously. The causes most frequently cited were stressful life events, evil spiriting or black magic, and the behavior of the patient's family members (such as arguments in the family, family members 'spoiling' the patient, shouting at the patient or not loving the patient enough) [13].

\section{Treatment adherence}

The education content to improve treatment adherence in schizophrenia includes schizophrenia facts, healthcare access, crisis prevention, the importance of treatment compliance, relapse prevention and management, physical health promotion, and dealing with schizophrenia problems including problem solving and coping skills [14-19]. Community involvements includes community mobilization to raise awareness on schizophrenia and community support [14].

A study describes the needs for primary caregiver to have good communication skills, stress management, and strategies for relaxation for the family [18]. Table 2 summarize the findings of the education delivery personnel and method.

\section{Table 2. Summary of reviewed studies in delivering education to improve treatment adherence}

\begin{tabular}{|c|c|c|c|}
\hline Author & $\begin{array}{c}\text { Publication } \\
\text { Year }\end{array}$ & $\begin{array}{c}\text { Personnel delivering the } \\
\text { education }\end{array}$ & Delivery of education \\
\hline Asher L, et al. ${ }^{14}$ & 2016 & $\begin{array}{l}\text { Community-based } \\
\text { rehabilitation worker (lay } \\
\text { health worker) }\end{array}$ & $\begin{array}{l}\text { Regular home-visit in } 12 \text { months, } \\
\text { divided into } 3 \text { phases of interventions }\end{array}$ \\
\hline $\begin{array}{l}\text { Ghadiri Vasfi M, } \\
\text { et al. } .^{15}\end{array}$ & 2015 & Not stated & $\begin{array}{l}\text { Multiple-family group sessions or } \\
\text { single-family sessions depending on the } \\
\text { needs of the group of patients }\end{array}$ \\
\hline Guo X, et al. ${ }^{16}$ & 2010 & $\begin{array}{l}\text { Therapist (psychiatrist or } \\
\text { clinical psychologist) }\end{array}$ & $\begin{array}{l}\text { Group session in a forum, once per } \\
\text { month for } 12 \text { months, one-hour session }\end{array}$ \\
\hline Hasan AA, et al. ${ }^{17}$ & 2015 & Psychiatrist & $\begin{array}{l}\text { Through six booklets given every two } \\
\text { weeks for } 12 \text { weeks }\end{array}$ \\
\hline Sharif F, et al. ${ }^{18}$ & 2012 & $\begin{array}{l}\text { Mental health nurse or } \\
\text { psychiatrist }\end{array}$ & $\begin{array}{l}\text { Group lectures using variety of } \\
\text { educational techniques, question and } \\
\text { answer, and group discussion period }\end{array}$ \\
\hline Thara R, et al. ${ }^{19}$ & 2005 & Not stated & $\begin{array}{c}\text { Two psychoeducation programs: } \\
\text { structured and informal }\end{array}$ \\
\hline
\end{tabular}

Personnel and tools for evaluating the education outcomes varies between each study. The measured outcomes for treatment adherence are appointment compliance, patient's clinical status and symptom severity, and relapse [14-19]. A systematic review and meta-analysis reviewed studies of community-based psychosocial intervention in low- and middle-income countries. The content and structure of the studies varied, but adherence management strategies are included in the education of schizophrenia [7].

\section{Preventing pasung}

Three articles reporting physical restraint and confinement of schizophrenia patients in rural and urban area were analyzed. Based on the content analysis, the following items were identified (Table 3). 
Table 3. Summary of reviewed studies in physical restraint and confinement

\begin{tabular}{|c|c|c|c|c|c|}
\hline Author & $\begin{array}{c}\text { Publication } \\
\text { Year }\end{array}$ & $\begin{array}{l}\text { Type of study / } \\
\text { Settings }\end{array}$ & $\begin{array}{l}\text { Reasons for physical } \\
\text { restraint and confinement }\end{array}$ & Needs gap & Recommendation \\
\hline $\begin{array}{l}\text { Asher L, } \\
\text { et al. }\end{array}$ & 2017 & $\begin{array}{l}\text { Qualitative } \\
\text { study / Rural }\end{array}$ & $\begin{array}{l}\text { Safety and protection of the } \\
\text { patient, protecting the } \\
\text { community, assumption that } \\
\text { people with schizophrenia } \\
\text { are dangerous and } \\
\text { predictable, stigma, } \\
\text { punishing the patient }\end{array}$ & $\begin{array}{l}\text { Lack access to } \\
\text { mental health } \\
\text { care }\end{array}$ & $\begin{array}{c}\text { Scaling up } \\
\text { accessible, affordable } \\
\text { and rights based } \\
\text { mental health care }\end{array}$ \\
\hline $\begin{array}{l}\text { Laila } \\
\mathrm{NH} \text {, et } \\
\text { al. }^{10}\end{array}$ & 2018 & $\begin{array}{l}\text { Qualitative } \\
\text { study / Rural }\end{array}$ & $\begin{array}{l}\text { Safety and protection of the } \\
\text { patient, costly mental } \\
\text { health, and dissatisfaction } \\
\text { with mental health services }\end{array}$ & $\begin{array}{c}\text { Lack of } \\
\text { information, } \\
\text { access, and } \\
\text { mental health } \\
\text { facilities }\end{array}$ & $\begin{array}{l}\text { Scaling up mental } \\
\text { health services, } \\
\text { emphasizing in } \\
\text { accessibility and } \\
\text { quality, especially in } \\
\text { rural settings }\end{array}$ \\
\hline $\begin{array}{l}\text { Tay JL, } \\
\text { et al. }\end{array}$ & 2017 & $\begin{array}{l}\text { Case-report / } \\
\text { Urban }\end{array}$ & $\begin{array}{l}\text { Beliefs that professional } \\
\text { western medicine was } \\
\text { ineffective and harmful, } \\
\text { black magic beliefs, and } \\
\text { "self-control" was more } \\
\text { efficacious than medicine }\end{array}$ & $\begin{array}{l}\text { Lack of mental } \\
\text { health literacy }\end{array}$ & $\begin{array}{l}\text { Empower and } \\
\text { educate the public, } \\
\text { strengthen } \\
\text { community } \\
\text { psychiatric services, } \\
\text { reduce treatment gap }\end{array}$ \\
\hline
\end{tabular}

One study in Ethiopia found that the primary reason of physical restraint and confinement in patient with schizophrenia is not due to lack of awareness, but due to lack of access to healthcare services [20]. However, the study conducted in Indonesia found that pasung was perceived as a practical solution and was an accepted norm in the community [10]. The shackled patient expressed the desire to see a doctor or to be admitted to a mental hospital, but families ignored the request due to various reasons [10].

\section{DISCUSSION}

Numerous studies have found that the problems of schizophrenia which includes barrier to identifying the disorder, be adherent to treatment, and pasung can be alleviated through patient and family education. While there are studies describing educational content to identify schizophrenia and to improve treatment adherence in lowand middle-income countries, we have not found any study exploring on educational content for patient and family to prevent pasung or physical restraint and confinement. However, it is important to note that the recurring reasons of restraining schizophrenia patients are stigma on the patient and the patient's aggressive behavior. Therefore, it is vital to include education on the facts of schizophrenia, the importance on adhering to treatment and follow-up, crisis management, and mechanism of referral to mental institutions or social services.

There are various methods to deliver schizophrenia education. One method is individual psychoeducation.
Another one is group psychoeducation or multifamily psychoeducation program. However, there has not been a convincing evidence that showed that those given individual psychoeducation differed in terms of compliance and relapse compared with those given group psychoeducation [22].

A study in Chennai, India compared structured multifamily psychoeducation program with informal multifamily psychoeducation program. The structured psychoeducation program provided discussion about schizophrenia and a forum for information sharing and interaction between families, while the informal education program includes screening of a movie and interactive session added with periodic reinforcer sessions. The problem with the structured program was to ensure regular attendance. It is concluded that the informal multifamily education program may be more suitable in such setting [19].

A model of community engagement of schizophrenia is found in Ethiopia, where community-based rehabilitation (CBR) intervention was conducted [14]. The CBR intervention recruited CBR workers to give them competence to educate patient and family about schizophrenia [14]. This model can be implemented in Indonesia, where there are limited resources on mental health professionals. Mental health professionals can educate and train the already existing community health cadres (semi-voluntary healthcare workers unique to Indonesia) in primary care and community health centers. It is also important to note that family members can educate others in the community. 
http://www.depkes.go.id/resources/download/infoterkini/materi_rakorpop_2018/Hasil Riskesdas 2018.pdf

\section{CONCLUSION}

Education for the families of patients with schizophrenia should include measures to help identify schizophrenia early, improve adherence, and prevent shackling. Family members can also be empowered to educate others in the community. Educational intervention on schizophrenia should be implemented in primary health facilities and community health centers. Education material should include schizophrenia facts and myths, early symptoms of schizophrenia, the importance of adherence to therapy and follow-up, crisis management, and mechanism of referral to mental institutions or social services. More studies on the content and method of education are warranted.

\section{REFERENCES}

[1] World Health Organization. ICD-10 Version:2016 [Internet]. ICD-10. 2016 [cited 2019 Oct 1]. Available from: https://icd.who.int/browse10/2016/en\#/F20-F29

[2] World Health Organization. ICD-11 - Mortality and Morbidity Statistics [Internet]. ICD-11. 2019 [cited 2019 Oct 1]. Available from: https://icd.who.int/browse11/1$\mathrm{m} / \mathrm{en} \# / \mathrm{http} \% 3 \mathrm{~A} \% 2 \mathrm{~F} \% 2 \mathrm{Fid}$.who.int $\% 2 \mathrm{Ficd} \% 2 \mathrm{Fentity} \% 2 \mathrm{~F}$ 405565289

[3] Idaiani S, Kusumawardani N, Ika R. Mental health research in Indonesia. Jakarta; 2019.

[4] Moreno-Küstner B, Martín C, Pastor L. Prevalence of psychotic disorders and its association with methodological issues. A systematic review and meta-analyses. PLoS One [Internet]. 2018 [cited 2019 Oct 10];13(4):e0195687. Available from: http://www.ncbi.nlm.nih.gov/pubmed/29649252

[5] Świtaj P, Anczewska M, Chrostek A, Sabariego C, Cieza A, Bickenbach J, et al. Disability and schizophrenia: a systematic review of experienced psychosocial difficulties. BMC Psychiatry [Internet]. 2012 Nov 9 [cited 2019 Jul 30];12:193. Available from: http://www.ncbi.nlm.nih.gov/pubmed/23137171

[6] Melva Ratnawati D, Surya Husada Bahagia Loebis M. Relationship of Burden with Characteristic Sociodemographic Caregiver in Schizophrenic patients. 2014 [cited 2019 Jul 30];4(21). Available from: www.iiste.org

[7] Asher L, Patel V, De Silva MJ. Community-based psychosocial interventions for people with schizophrenia in low and middle-income countries: systematic review and meta-analysis. BMC Psychiatry [Internet]. 2017 Dec 30 [cited 2019 Jul 30];17(1):355. Available from: http://www.ncbi.nlm.nih.gov/pubmed/29084529

[8] Kesehatan K, Penelitian B, Kesehatan P. HASIL UTAMA RISKESDAS 2018 [Internet]. [cited 2019 Jul 31]. Available

from:
[9] Norman R, Lecomte T, Addington D, Anderson E. Canadian Treatment Guidelines on Psychosocial Treatment of Schizophrenia in Adults. Can J Psychiatry [Internet]. 2017 [cited 2019 Oct 1];62(9):617-23. Available from: http://www.ncbi.nlm.nih.gov/pubmed/28703017

[10] Laila NH, Mahkota R, Krianto T, Shivalli S. Perceptions about pasung (physical restraint and confinement) of schizophrenia patients: a qualitative study among family members and other key stakeholders in Bogor Regency, West Java Province, Indonesia 2017. Int J Ment Health Syst [Internet]. 2018 [cited 2019 Oct 1];12:35. Available

http://www.ncbi.nlm.nih.gov/pubmed/29983734

[11] Al-HadiHasan A, Callaghan P, Lymn JS. Qualitative process evaluation of a psycho-educational intervention targeted at people diagnosed with schizophrenia and their primary caregivers in Jordan. BMC Psychiatry. 2017;17(1):1-17.

[12] Loughland C, Cheng K, Harris G, Kelly B, Cohen M, Sandhu $\mathrm{H}$, et al. Communication of a schizophrenia diagnosis: A qualitative study of patients' perspectives. Int J Soc Psychiatry. 2015;61(8):729-34.

[13] Koschorke M, Padmavati R, Kumar S, Cohen A, Weiss $\mathrm{H}$, CHatterjee $\mathrm{S}$, et al. Experiences of stigma and discrimination faced by family caregivers of people with schizophrenia in India. Soc Sci Med [Internet]. 2017;178:66-77. Available from:

[14] Asher L, De Silva M, Hanlon C, Weiss HA, Birhane $\mathrm{R}$, Ejigu DA, et al. Community-based Rehabilitation Intervention for people with Schizophrenia in Ethiopia (RISE): Study protocol for a cluster randomised controlled trial. Trials [Internet]. 2016;17(1):1-14. Available from: http://dx.doi.org/10.1186/s13063-016-1427-9

[15] Vasfi MG, Moradi-Lakeh M, Esmaeili N, Soleimani $\mathrm{N}$, Hajebi A. Efficacy of aftercare services for people with severe mental disorders in Iran: A randomized controlled trial. Psychiatr Serv. 2015;66(4):373-80.

[16] Guo X, Zhai J, Liu Z, Fang M, Wang B, Want C, et al. Antipsychotic medication alone versus combined with psychosocial intervention on outcomes of early stage schizophrenia: A randomized, one-year study. Arch Gen Psychiatry. 2010;67(9):895-904.

[17] Hasan AA, Callaghan P, Lymn JS. Evaluation of the impact of a psycho-educational intervention for people diagnosed with schizophrenia and their primary caregivers in Jordan: A randomized controlled trial. BMC Psychiatry. 2015;15(1):1-10.

[18] Sharif F, Shaygan M, Mani A. Effect of a psychoeducational intervention for family members on caregiver burdens and psychiatric symptoms in patients with schizophrenia in Shiraz, Iran. BMC Psychiatry [Internet]. http://dx.doi.org/10.1016/j.socscimed.2017.01.061 
- A case report about restraining a mentally unwell family member at home for over a decade. Asian J Psychiatr [Internet]. 2017;26:146-8. Available from: http://dx.doi.org/10.1016/j.ajp.2017.02.004

[22] Xia J, Merinder LB, Belgamwar MR. Psychoeducation for schizophrenia. Cochrane database Syst Rev [Internet]. 2011 Jun 15 [cited 2019 Oct 2];(6):CD002831. Available from: http://www.ncbi.nlm.nih.gov/pubmed/21678337 2017;1(13):1-14.

[21] Tay JL, Chan CYW, Ho ZC, Lal M. The ties that bind 